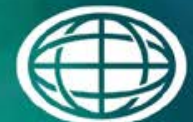

Savannah River

National Laboratory

OPERATED BY SAVANNAH RIVER NUCLEAR SOLUTIONS

SRNL-STI -2013-00551

A U.S. DEPARTMENT OF ENERGY NATIONAL LABORATORY • SAVANNAH RIVER SITE • AIKEN, SC

\title{
Reductions without Regret:
}

\section{Historical Perspectives}

9 September 2013

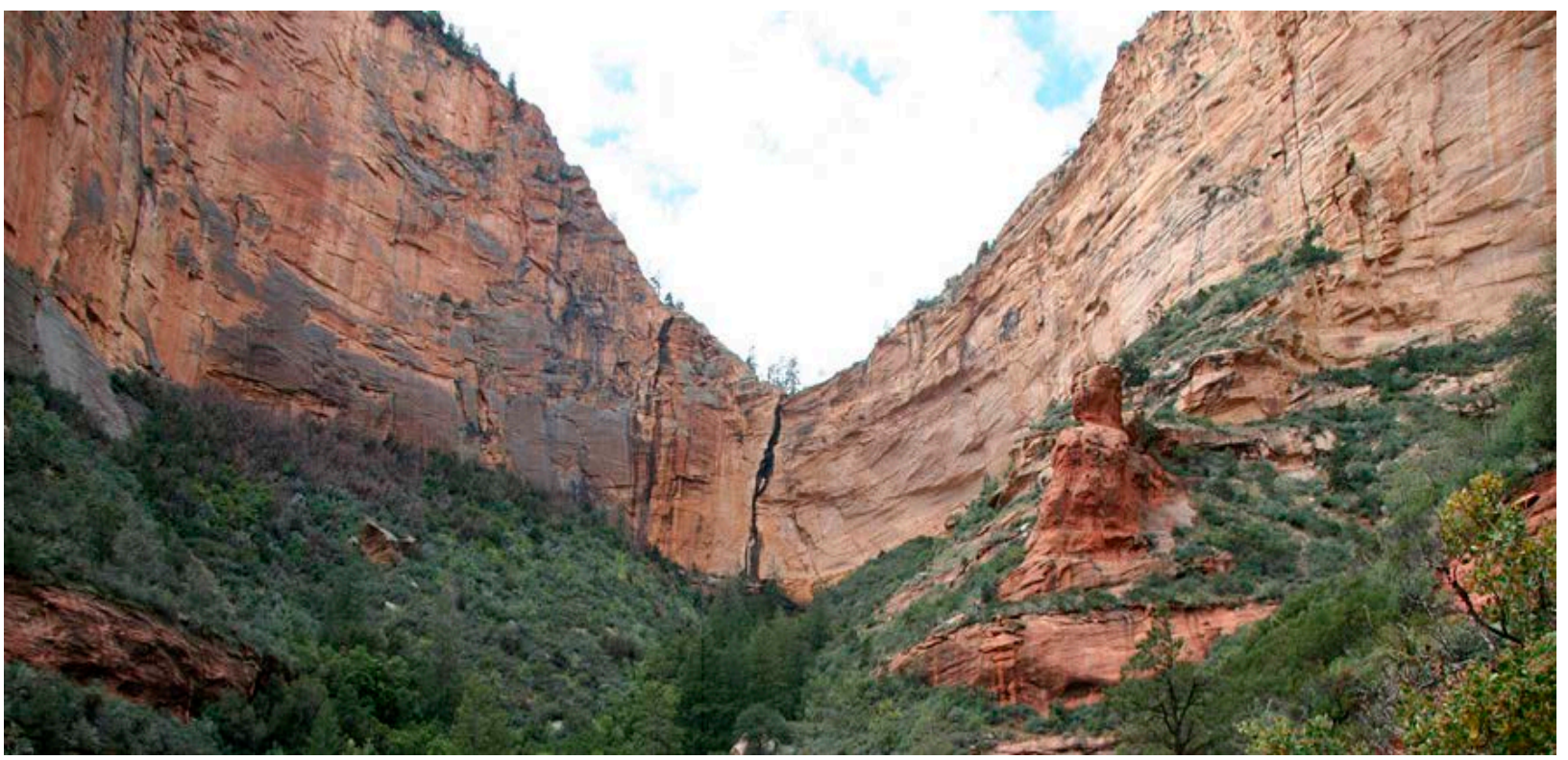

John A. Swegle

Douqlas J. Tincher 
The analysis contained herein is that of the authors and does not reflect the views or positions of the Savannah River National Laboratory, the National Nuclear Security Administration, or the U.S. Department of Energy.

Savannah River National Laboratory

Aiken, SC 29808

John A. Swegle, 735-11A, Room 113, (803)725-3515

Douglas J. Tincher, 735A, Room B102, (803)725-4167 


\section{Reductions without Regret: Historical Perspectives}

John A. Swegle and Douglas J. Tincher

Savannah River National Laboratory

This is the first of three papers (in addition to an introductory summary) aimed at providing a framework for evaluating future reductions or modifications of the U.S. nuclear force, first by considering previous instances in which nuclear-force capabilities were eliminated; second by looking forward into at least the foreseeable future at the features of global and regional deterrence (recognizing that new weapon systems currently projected will have expected lifetimes stretching beyond our ability to predict the future); and third by providing examples of past or possible undesirable outcomes in the shaping of the future nuclear force, as well as some closing thoughts for the future.

This paper examines the circumstances and consequences of the elimination of

- The INF-range Pershing II ballistic missile and Gryphon Ground-Launched Cruise Missile (GLCM), deployed by NATO under a dual-track strategy to counter Soviet intermediate-range missiles while pursuing negotiations to limit or eliminate all of these missiles.

- $\quad$ The Short-Range Attack Missile (SRAM), which was actually a family of missiles including SRAM A, SRAM B (never deployed), and SRAM II and SRAM T, these last two cancelled during an over-budget/behind-schedule development phase as part of the Presidential Nuclear Initiatives of 1991 and 1992.

- The nuclear-armed version of the Tomahawk Land-Attack Cruise Missile (TLAM/N), first limited to shore-based storage by the PNIs, and finally eliminated in deliberations surrounding the 2010 Nuclear Posture Review Report.

- The Missile-X (MX), or Peacekeeper, a heavy MIRVed ICBM, deployed in fixed silos, rather than in an originally proposed mobile mode. Peacekeeper was likely intended as a bargaining chip to facilitate elimination of Russian heavy missiles. The plan failed when START II did not enter into force, and the missiles were eliminated at the end of their intended service life.

- The Small ICBM (SICBM), or Midgetman, a road-mobile, single-warhead missile for which per-unit costs were climbing when it was eliminated under the PNIs.

Although there were liabilities associated with each of these systems, there were also unique capabilities; this paper lays out the pros and cons for each. Further, we articulate the capabilities that were eliminated with these systems.

\section{Overview of the Eliminations}

Here, we consider a number of previously eliminated nuclear-weapon systems, non-strategic and strategic, and the nuclear-deterrence capabilities they represented. Specifically, we consider the Pershing II and Gryphon Ground-Launched Cruise Missile (GLCM); the Short-Range Attack 
Missile (SRAM); the nuclear-armed version of the Tomahawk Land-Attack Cruise Missile (TLAM/N); the Small ICBM (SICBM)/Midgetman; and the MX/Peacekeeper ICBM.

Pershing II and the GLCM were eliminated under the terms of the INF Treaty. Peacekeeper ultimately served out its lifetime as the United States' most advanced and capable ICBM, but also something of a failed bargaining chip in an attempt to secure the elimination of the Soviet Union's and Russia's heavy MIRVed missiles. The other systems were all strongly affected by President George H.W. Bush’s voluntary reduction and elimination measures of 1991 and 1992: ${ }^{1}$

- The reductions in the Presidential Address of 27 September $1991,{ }^{2}$ matched qualitatively by Presidents Gorbachev and Yeltsin, with the following features for the United States:

o Short-range ground-launched weapon systems were eliminated, but air-delivered capabilities were retained;

o Tactical naval nuclear weapons, including weapons delivered by carrier-based aircraft, were removed from normal deployment, with some eliminated and the rest moved to storage;

o Rail-mobile and road-mobile ICBM development was terminated; and

o SRAM II and SRAM T development was cancelled.

- President Bush's announcement, in his 1992 State of the Union message, ${ }^{3}$ of the following:

o Limitation of the B-2 bomber fleet to 20 aircraft, from the originally-planned 132;

o Cancellation of Midgetman; and

o Halting further production of the W88 SLBM warhead, the Peacekeeper ICBM, and the Advanced ALCM.

The unilateral, non-binding cuts in the Presidential Nuclear Initiatives (PNIs) of 1991 and 1992 were an attempt by both sides to reduce tensions, as well as the budget demands of nuclear weapons development, in the hopeful aftermath of the Cold War. However, they were ultimately only partially effective on the Russian side.

\section{Pershing II and the Ground-Launched Cruise Missile (GLCM)}

Pershing II, armed with the W85 nuclear warhead, and the GLCM, armed with the W84, were highly-accurate (the former employing a maneuvering reentry vehicle, or MaRV), theater-based missiles with ranges of 1,770 and 2,500 kilometers, respectively. Both were eliminated entirely in 1988 under the terms of the INF Treaty in return for Soviet Union's total elimination of the SS-20 and SS-23, as well as the older SS-4 and SS-5 intermediate-range ballistic missiles (IRBMs). ${ }^{*}$ That outcome was the result of an act of nuclear brinksmanship (see Figure 1), in which NATO voted in late 1979 to deploy Pershing II and the GLCM in Europe as part of a dual-track plan to counter the 3-warhead, 5,000-kilometer-range SS-20 while simultaneously calling for arms-control negotiations to reduce the numbers of these missiles to the lowest possible levels. The high accuracy and short flight times of the INF-range missiles between the Soviet Union and NATO countries created a serious First-Strike Stability issue for the two sides, and the Pershing II deployments in Europe generated an enormous controversy in NATO countries.

\footnotetext{
* We note that the INF captures what is defined there as "shorter-range” (500-1,000 km), as well as medium(1,000-3,500 km), and intermediate-range (3,500-5,500 km) ballistic and cruise missiles. Here we refer to all of these ranges as "INF-range."
} 


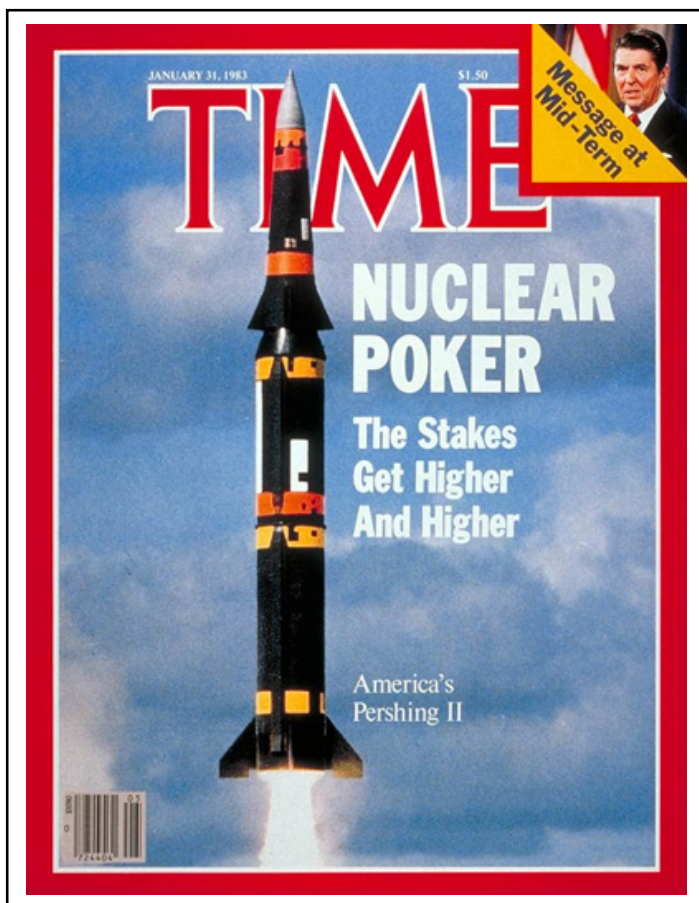

The politics of deploying and eliminating INFrange missiles illustrates the complexity and subtlety of Cold-War calculations. According to a summary ${ }^{4}$ of the declassified version of a State Department cable describing the 1979 final report from the NATO High Level Group on the Pershing II and GLCM deployments, this move was meant to signal "Alliance resolve" and visibly fill any gaps in the escalation spectrum. According to Richard Garthoff, the warhead count on NATO INF-range missiles was kept at a lower level that of the Soviet side to signal that escalation to U.S. strategic systems was still possible and that isolation of a nuclear conflict to Europe was unlikely. ${ }^{5}$ To demonstrate NATO-wide support, GLCMs were based not only in Germany, but also in Belgium, the Netherlands, and Italy. Further, to prevent the driving of wedges in the Alliance, the United States insisted that treaty negotiations be bipolar; Germany's coincident elimination of its Pershing IA missiles, which were to be armed with U.S. nuclear warheads, was formally a unilateral move. ${ }^{6}$ Ultimately, the "zero option" of total elimination met with approval in Japan, where Prime Minister Yasuhiro Nakasone had been lobbying against any shift of such missiles to the east of the Ural Mountains. ${ }^{7}$

\section{Short-Range Attack Missile (SRAM)}

The SRAM A (AGM-69A, armed with the W69) was deployed between 1972 and 1975 for delivery by the B-52 and FB-111. ${ }^{8}$ The initial purpose of these supersonic missiles was to strike air-defense targets to aid bombers in penetrating enemy air space; later, they were also intended to strike selected strategic targets. This original version was finally retired in 1990 because of motor reliability and warhead safety issues.

Two attempts were made to modernize and upgrade the original SRAM. Development of the SRAM B (AGM-69B) with a new motor to address motor storability problems and a new warhead to meet modern nuclear safety requirements, the W80, began in the late $1970 \mathrm{~s},{ }^{9}$ but was cancelled in 1978. When the B-1B bomber program was restarted in 1981, development began on a new SRAM II (AGM-131A, to be armed with the W89) for the bomber. ${ }^{10}$ In addition, a modification, the SRAM T (AGM-131B, armed with the W91) was to be developed for delivery by the F-15E Strike Eagle dual-role fighter. A lighter, simpler, longer-lived, and more reliable rocket motor was designed to increase SRAM T range.

Unfortunately, as recounted in GAO reporting from 1991-1992, ${ }^{11}$ problems with maneuverability and range (the latter tracing to issues with the propellant) were compromising the ability of SRAM II to meet the requirements to strike hardened targets from beyond enemy defenses and thus enhance bomber survivability. By the time President George H.W. Bush announced the 
cancellation of the programs in 1991, the range of SRAM II had been reduced to about that of SRAM A, and both SRAM II and SRAM T were years behind schedule at double the originally projected program costs. Cancellation of SRAM II and SRAM T left the U.S. with long-range, subsonic air-launched cruise missiles for delivery by strategic bombers, and B61 gravity bombs (see

Table 1) for delivery by U.S. and NATO

\begin{tabular}{|c|c|c|c|}
\hline & SRAM II & ALCM & B61 \\
\hline Top Speed & Mach 2+ & High subsonic & -- \\
\hline Range (km ) & 400 & $2,400+$ & -- \\
\hline Length (m) & 3.18 & 6.3 & 3.56 \\
\hline Diameter (m) & 0.39 & 0.62 & 0.33 \\
\hline Mass (kg) & 900 & 1,430 & 320 \\
\hline
\end{tabular}
tactical dual-capable aircraft (T-DCA).

\section{Tomahawk Land-Attack Cruise Missile/Nuclear (TLAM/N)}

TLAM/N (BGM-109A), armed with the W80 nuclear warhead, provided medium-range (2,500 kilometers), tactical-nuclear delivery from a sea-based platform that did not require foreign nuclear basing. First deployed in the 1970s and carried by Los Angeles-class submarines, they were guided by a combination of inertial guidance and terrain contour matching (TERCOM). ${ }^{\dagger}$

At-sea basing of TLAM/N was curtailed by the PNIs of 1991 and 1992, under which TLAM/N was removed from ships and submarines and placed in central storage on shore "under normal circumstances.” This created the logistical challenge of having to return to port, or of developing alternate transport procedures to another location, to reload them onto submarines if desired. This would also have created a situation that restricted U.S. flexibility, in that redeploying TLAM/N under a situation of enhanced tensions would, if revealed, further raise tensions, whether that strategic signal was intended to be sent or not.

In addition to these logistical and flexibility issues, reliability had become a concern with TLAM/N based on the experience with conventionally-armed TLAM. In a 12 April 2003 press conference, ${ }^{12}$ Adm. Timothy Keating, the commander of all maritime forces for the Operation Iraqi Freedom,

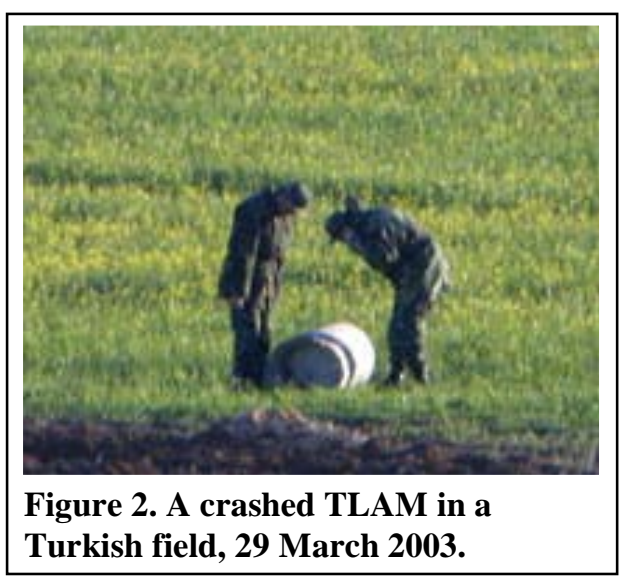
indicated that "less than ten" of over 800 conventionallyarmed TLAMs launched - " 1 to 1.25 percent" - had failed to reach their targets and were found in Turkey or Saudi Arabia (see Figure $\mathbf{2}^{13}$ ). This of course raised the specter of a loss-of-warhead scenario if a TLAM/N were to crash without properly destroying itself, in which case a number of possible scenarios presented themselves, depending on whether the weapon crashed over friendly or unfriendly territory; whether it was recovered by a nuclear-armed or non-nuclear state, or a non-state actor; and whether the very difficult task of accessing the

${ }^{\dagger}$ Different or upgraded guidance systems were employed on subsequent versions of conventionally-armed TLAM: the Tactical Anti-Ship Missile (TASM), and TLAM-C, -D, and -E. 
warhead intact could be accomplished in the face of the weapon's security features

Even so, TLAM/N was a tangible signal of extended deterrence, particularly in Northeast Asia. The April 2009 Final Report of the Congressional Commission on the Strategic Posture of the U.S. ${ }^{14}$ highlighted the concerns of Asian allies regarding TLAM/N retirement, and a subsequent clarifying letter of December 2009 from Japan's Foreign Minister to Secretary of State Clinton, while expressing support for nuclear disarmament, requested continued clarification of the effect of retirement on extended deterrence for Japan. ${ }^{15}$ These highlighted two features of extended deterrence in Northeast Asia. First, it showed the dependence of Japanese reception of U.S. extended deterrence on the political climate there: the Japanese election of 20 August 2009 featured a change in parties from the Liberal Democratic Party (under which comments were made to the Congressional Commission) to the Democratic Party of Japan (the party of the Foreign Minister writing the December letter). Second, it showed the importance of extended deterrence for Japan's national security, whatever the accepted means of providing it.

In the face of the aforementioned challenges, and others including the costs of modernizing TLAM/N, and in consideration of the ability to supplant this deterrent with other existing systems, and finally to meet the stated goal of reducing U.S. dependence on nuclear weapons, the elimination of TLAM/N was announced in the 2010 Nuclear Posture Review Report. Shortly thereafter, new nuclear deterrence consultations were established with both Japan and South Korea:

- Formation of an Extended Deterrence Policy Committee between the U.S. and the Republic of Korea was announced on 8 October 2010 in the Joint Communique of the U.S.-ROK Security Consultative Meeting in Washington, DC. ${ }^{16}$

- Establishment of an extended deterrence dialogue with Japan was announced in the joint statement issued at the conclusion of the 21 June 2011 U.S.-Japan Security Consultative Committee meeting. ${ }^{17}$

Presumably, in the rough equation for deterrence, credibility = capability $x$ commitment, any reduction in capability with the retirement of TLAM/N is to be met, or exceeded, by the increased commitment shown to U.S. allies in Northeast Asia through the committee and dialogue.

\section{Missile-X (MX) ICBM, "Peacekeeper"}

From 1986 to 2005, Missile-X was the epitome of U.S. ICBM design and manufacture.

Peacekeeper's advanced technologies modernized and improved U.S. nuclear deterrence and provided substantially-upgraded capacity: ${ }^{18}$

- Peacekeeper was the first U.S. ICBM to use "cold launch" technology, with steam pressure ejecting the missile from its silo to 150 feet above the silo doors, where first-stage ignition occurred;

- The missile used Kevlar fiber-reinforced composite construction for its solid-propellant rocket motor cases, which reduced structural mass versus traditional metal construction;

- It incorporated telescoping exit cones on its solid-fuel rocket engines to reduce missile length within the silo while retaining the performance of a longer missile in flight; and

- Its advanced solid propellants further boosted its payload throw weight, while its advanced micro-electronic guidance technologies enhanced accuracy. 
Originally conceived in 1971 by the Strategic Air Command as a new, largest-ever, U.S. ICBM to replace what was believed to be obsolete Minuteman technology, the matter of how to provide a survivable basing mode for Peacekeeper created a painful, years-long controversy spanning the Carter and Reagan administrations that dogged the missile to the end of its deployment. ${ }^{19}$ The problem was that defense analysts judged that two of the new SS-18 warheads could destroy a tenwarhead silo-based Peacekeeper, creating a 5-to-1 disadvantage in the so-called "exchange ratio.” This was regarded as the possible source of strategic instability. ${ }^{20}$

After repeated consideration of a range of options including movement between Multiple Protective Shelters (MPSs), or rail-mobile launchers, or the unproven "superhard silo" - a number of which aroused strong opposition from governors and representatives in states slated to host Peacekeeper - President Reagan chose possibly the most vulnerable option: basing in existing Minuteman silos. According to Pomeroy, this was the fastest route to deployment as a means of leveraging Peacekeeper to force arms control negotiations that would reduce or eliminate corresponding Soviet systems. ${ }^{21}$ In 1993, the United States and Russia signed START II dictating the elimination of all multiple-warhead ICBMs. Under the circumstances, continued maintenance of Peacekeeper as a single-warhead delivery system made no sense, and even though START II was never ratified, deactivation of Peacekeepers began in 2003 and was completed in $2005 .{ }^{22}$

Peacekeeper embodied several capabilities or options for the U.S. nuclear force:

- The ability to deliver more than three MIRVs, which is the theoretical capability for Minuteman III (LGM-30G);

- The ability to deliver any future weapon system physically larger or heavier than the capacity of the upgraded Minuteman III; retaining Peacekeeper could have enabled the delivery of large, heavy maneuverable reentry vehicles (MaRVs) or boost-glide vehicles (BGVs), albeit at the expense of the increased verification burden created by the upload capacity of such a large booster; and

- The potential ability to deliver a ballistic RV along a non-Great Circle route trajectory in order to support weapon delivery options that avoided the political and legal complications of overflying Russia or other nations.

\section{Small ICBM “Midgetman” (SICBM)}

The SICBM concept represented a highly-optimized means of delivering a single nuclear warhead to roughly 11,000-km range with accuracy rivaling the MX (indeed, it was designed to carry the same Mark-21/W87 warhead). ${ }^{23}$ The basing schema of widely-dispersed, self-contained, road- and off-road-mobile launchers provided enhanced survivability versus silos. ${ }^{24}$ SICBM achieved its first successful test flight in mid-1991. However, President George H.W. Bush cancelled the SICBM program in early 1992 as a result of reduced strategic tensions due to the end of the Cold War. ${ }^{25}$ Shortly afterward, Russia cancelled development of its own single-warhead Kuryer mobile ICBM.

Cancellation of SICBM made political and economic sense. The political pressure to curtail what was already a controversial project was substantial. The ever-reduced number of SICBMs to be procured, coupled to evolving system requirements, led to highly-scrutinized per-unit price escalations. Besides, Peacekeeper was already under construction with recovery of R\&D costs well 
underway, whereas the SICBM price comparisons included all of these up-front and recoverable costs, making the larger Peacekeeper appear to be substantially less expensive.

Ultimately, SICBM's mobile launch platform could have led to a far more survivable ICBM force, at less expense than maintaining readiness for all silos to retain the high number of candidate targets facing enemy forces. SICBM would have been a wholly-new system optimized for singlewarhead ICBM delivery. Launch could have occurred from anywhere the launcher could drive or anywhere the launcher could be transported by rail, ship, or air. ${ }^{26}$ Eventual negotiations for fewer warheads and missiles could theoretically be more acceptable as a result of the increased survivability of each remaining mobile missile versus fixed silos. Verification would be simpler in that SICBM was designed to only accommodate one RV. Finally, contingency replacement of existing, or breakout production of new, airframes would have been simpler if the production lines of the newer system had been retained and used for spares throughout the program's lifetime.

\section{Pros and Cons of the Eliminated Nuclear Capabilities}

In Table 2, we summarize the capabilities of the non-strategic nuclear weapon systems described here, the contributions they offered for nuclear deterrence (the pros), and the complications they presented for stability or nuclear security (the cons).

\begin{tabular}{|c|c|c|c|}
\hline & Capability & Pro & Con \\
\hline Pershing II & $\begin{array}{l}\text { INF-range ballistic } \\
\text { missile } \\
\text { Maneuvering RV }\end{array}$ & $\begin{array}{l}\text { Responsive theater } \\
\text { ballistic missile } \\
\text { Highly accurate }\end{array}$ & $\begin{array}{l}\text { Strongly destabilizing } \\
\text { Overseas nuclear weapon basing }\end{array}$ \\
\hline GLCM & $\begin{array}{l}\text { INF-range cruise } \\
\text { missile }\end{array}$ & $\begin{array}{l}\text { Responsive theater } \\
\text { nuclear weapon } \\
\text { Highly accurate }\end{array}$ & $\begin{array}{l}\text { Strongly destabilizing } \\
\text { Overseas nuclear weapon basing } \\
\text { Subsonic, potential in-flight loss of weapon }\end{array}$ \\
\hline SRAM II/T & $\begin{array}{l}\text { 100s kilometer } \\
\text { range tactical } \\
\text { standoff missile }\end{array}$ & $\begin{array}{l}\text { Responsive tactical } \\
\text { standoff weapon } \\
\text { Supersonic } \\
\text { Potentially highly } \\
\text { accurate }\end{array}$ & $\begin{array}{l}\text { Overseas nuclear weapon basing } \\
\text { Potential in-flight loss of weapon } \\
\text { (reduced chance) } \\
\text { Possibly redundant with ALCM } \\
\text { Program behind schedule and over } \\
\text { budget when cancelled }\end{array}$ \\
\hline TLAM/N & $\begin{array}{l}\text { Sea-launched } \\
\text { regional deterrent }\end{array}$ & $\begin{array}{l}\text { Responsive theater } \\
\text { nuclear weapon } \\
\text { Highly accurate } \\
\text { Can avoid overseas } \\
\text { nuclear basing }\end{array}$ & $\begin{array}{l}\text { Logistics of deployment under PNIs } \\
\text { Subsonic, potential in-flight loss of weapon } \\
\text { Launch temporarily locates submarine } \\
\text { Needing modernization when eliminated }\end{array}$ \\
\hline
\end{tabular}

INF-range missiles were eliminated by the United States and the Soviet Union because of the strategic instability they created. Since then, though, confrontations involving MRBM- and IRBMarmed nations have developed - or are developing - in several key regions outside Europe:

- In the Middle East, Israel possesses Jericho-II (1,500 kilometers), and Iran is allegedly developing Sejil-2/3 (2,500-4,000 kilometers), Shahab-4 (2,000-4,000 kilometers), and BM-25 (2,500-4,000 kilometers); 
- In South Asia, India has deployed Agni-II (2,000-3,000 kilometers), and Agni-IV (3,0003,500 kilometers), and has others in the R\&D phase, and Pakistan has Ghauri-III and the Shaheen-3+ series all in the R\&D phase; and

- In Northeast Asia, North Korea is developing IRBMs (Musudan/BM-25, as well as Unha-3 and $\mathrm{KN}-08$, the range of which could extend into ICBM territory), and China possesses DF-4 (4,500-5,000 km) and DF-21 (2,150 km) and has others under development.

Even in the absence of the INF Treaty, an examination of sample ranges between example basing points in the three regions - Aviano Air Base in Italy for the Middle East, British territory at Diego Garcia for the Indian Ocean region, and Anderson Air Force Base on Guam for the Western Pacific - shows that ranges to points in the Middle East, South Asia, and the Western Pacific all exceed the range of Pershing II, requiring a more muscular missile closer in performance to the SS-20 or Midgetman (see Table 3). We note that of course basing at Aviano would only reprise the tense

\begin{tabular}{|l|c|l|c|l|c|}
\hline $\begin{array}{c}\text { From Guam } \\
\text { to: }\end{array}$ & $\begin{array}{c}\text { Distance } \\
\mathbf{( k m )}\end{array}$ & $\begin{array}{c}\text { From Diego } \\
\text { Garcia to: }\end{array}$ & $\begin{array}{c}\text { Distance } \\
\mathbf{( k m})\end{array}$ & $\begin{array}{c}\text { From Aviano } \\
\text { AB to: }\end{array}$ & $\begin{array}{c}\text { Distance } \\
(\mathbf{k m})\end{array}$ \\
\hline Beijing & 4,000 & Abu Dhabi & 3,900 & Abu Dhabi & 4,400 \\
\hline Hanoi & 4,200 & Bandar Abbas & 4,100 & Bandar Abbas & 4,400 \\
\hline Manila & 2,550 & Colombo & 4,000 & Cairo & 2,400 \\
\hline Pyongyang & 3,400 & Islamabad & 4,400 & Damascus & 2,400 \\
\hline Quanzhou & 3,000 & Karachi & 3,500 & Kiev & 1,400 \\
\hline Seoul & 3,200 & Kolkota & 3,700 & Minsk & 1,400 \\
\hline Shanghai & 3,100 & Muscat & 3,600 & Moscow & 2,100 \\
\hline Shenzen & 3,400 & New Delhi & 4,000 & Riyadh & 3,800 \\
\hline Singapore & 4,700 & Riyadh & 4,500 & St. Petersburg & 1,900 \\
\hline Tokyo & 2,500 & Singapore & 3,600 & Tehran & 3,400 \\
\hline \multicolumn{7}{|l|}{ Yangon } & 5,200 & Tehran & 5,200 & Tel Aviv & 2,400 \\
\hline $\begin{array}{l}\text { Table 3. Distances between example points for a hypothetical consideration of medium- } \\
\text { and intermediate-range missile basing. }\end{array}$
\end{tabular}

and unstable Cold War situation that created a need on both sides for the INF Treaty, and which would likely be politically untenable in all but the most difficult-to-envision circumstances. Basing options in the Middle East or Northeast Asia that would shorten the distances there, possibly even involving deployment of mobile missiles with their transporter-erector launchers from the U.S. using C-17s, could be imagined, but the political-military issues involved are substantial, complex, and beyond the scope of this paper. Clearly, submarine basing of a conventionally-armed missile, or use of SLBMs or ALCMs, would have to be evaluated as alternatives.

Context is significant for the elimination of SRAM and TLAM/N. At the time of their elimination, both would have required significant further expenditures to either reach or continue deployment: 
SRAM was years behind schedule, well over budget, and slipping in promised performance. TLAM/N was limited by the pledge that it would normally be kept on-shore in central storage, which raised the issue that its deployment to sea would likely be not only a response to a crisis, but also a very strong signal that could raise tensions even further. Further, in-flight failures of conventionally-armed TLAMs, although limited in number, posed the prospect of a lowprobability/high-consequence loss-of-weapon event for TLAM/N. In this context, elimination of SRAM and TLAM/N, were interpretable as the result of a confluence of programmatic opportunism in cancelling troubled programs and strategic optimism at the end of the Cold War or in the context of reducing the role of nuclear weapons in U.S. security strategy.

Table 4 summarizes the pros and cons of the eliminated strategic nuclear weapons.

\begin{tabular}{|c|l|l|l|}
\hline \multicolumn{1}{|c|}{ Capability } & \multicolumn{1}{c|}{ Pro } & \multicolumn{1}{c|}{ Con } \\
\hline Peacekeeper & $\begin{array}{l}\text { Heavy lift } \\
\text { Heavily MIRVed } \\
\text { High-energy } \\
\text { booster }\end{array}$ & $\begin{array}{l}\text { Highly accurate } \\
\text { Surviving missiles highly } \\
\text { destructive even in small } \\
\text { numbers } \\
\text { Economies of scale at large } \\
\text { force sizes }\end{array}$ & $\begin{array}{l}\text { Silo basing vulnerable, creating a highly } \\
\text { attractive target } \\
\text { Mobile basing in Multiple Protected } \\
\text { Shelters highly unpopular } \\
\text { Superhard silos not fully explored } \\
\text { Upload capacity creates verification } \\
\text { challenge }\end{array}$ \\
\hline Midgetman & $\begin{array}{l}\text { Road-mobile } \\
\text { Optimized single- } \\
\text { warhead missile }\end{array}$ & $\begin{array}{l}\text { Accuracy approaching that of } \\
\text { silo-based systems } \\
\text { Single warhead simplifies } \\
\text { verification }\end{array}$ & $\begin{array}{l}\text { Additional cost created by need to build } \\
\text { stand-alone system that doesn't } \\
\text { capitalize on existing silos } \\
\text { Mobile basing potentially problematic } \\
\text { with hosting states }\end{array}$ \\
\hline
\end{tabular}

Table 4. Capabilities, pros, and cons of the eliminated strategic nuclear weapon systems discussed here.

As recounted by Pomeroy, the missile concept that evolved into Peacekeeper was always based on the assumption that the missile would have some sort of mobile or relocatable basing scheme to increase its survivability. Based in existing Minuteman silos, Hobson showed that Peacekeeper suffered a highly disadvantageous 5-to-1 loss ratio to a pair of incoming warheads. This is potentially the source of a so-called First-Strike Instability ${ }^{27}$ in which the U.S. leadership might have felt a "use or lose" imperative to launch preemptively, or on warning of attack, in order to prevent the loss of the substantial part of its nuclear force tied up in vulnerable Peacekeeper warheads. Midgetman, on the other hand, with its dispersed force of single-warhead missiles, was not the source of such a strategic instability. And the instability situation was not so clear-cut: submarine-based missiles (for which accuracy was improving with the transition from Polaris to Trident) and the possible addition of Midgetman to the force, provided a survivable, and therefore at least partially, stabilizing backup. Nevertheless, the potential instability associated with heavilyMIRVed missiles was a driving force in the negotiation in START II, which provided for the complete elimination of ICBMs carrying more than one warhead.

START II never entered into force. Russia continues to deploy MIRVed missiles, silo-based and road-mobile, along with mobile, single-warhead ICBMs and submarine-based missiles that strengthen strategic stability. Beyond the issue of stability, consider two other perspectives: 
- Multiple-warhead ICBMs can be used to change the offense-defense dynamics in the face of U.S. ballistic missile defense by making it easier to synchronize the launch of a larger number of warheads in order to overpower the defense, since fewer missiles are required for the same number of warheads.

- The relative numbers of MIRVed and single-warhead ICBMs can influence expected escalation dynamics. If one faces an adversary with heavily-MIRVed, silo-based missiles, the putative attacker is presumably put in a position of attempting to take them all or accept the heavy consequences of retaliation by any surviving missiles. In this sense, the deployment of heavily-MIRVed missiles can "steepen the escalation ladder," creating a heavy burden on the potential attacker to be able to mount a very large initial attack. This steepening of the escalation ladder both raises the bar for first use, but potentially increases the planned size of an initial exchange.

\section{References}

1 S. Koch, The Presidential Nuclear Initiatives of 1991-1992, September 2012, National Defense University Press; see Appendix 1 for the texts of all initiatives.

2 President George H.W. Bush, Address to the Nation on Reducing United States and Soviet Nuclear Weapons, 27 September 1991, available from the website of the George Bush Presidential Library and Museum, http://bushlibrary.tamu.edu/research/public_papers.php?id=3438\&year=1991\&month=9.

3 President George H.W. Bush, State of the Union Address, January 28, 1992, available online from http://millercenter.org/president/speeches/detail/5531.

4 Redacted and declassified version of State Department cable 247871, 21 September 1979, HLG: US Draft Report, summarized and available through the website of The National Security Archive of George Washington University, http://www.gwu.edu/ nsarchiv/nukevault/ebb301/\#6.

5 R. L. Garthoff, Détente and Confrontation: U.S.-Soviet Relations from Nixon to Reagan, Washington, D.C., Brookings Institution, 1994.

6 Treaty Between The United States Of America And The Union Of Soviet Socialist Republics On The Elimination Of Their Intermediate-Range And Shorter-Range Missiles (INF Treaty): Narrative, available from the U.S. Department of State website, http://www.state.gov/t/avc/trty/102360.htm\#text.

7 See, for example, L. Hughes, "Why Japan Will Not Go Nuclear (Yet), International and Domestic Constraints on the Nuclearization of Japan,” International Security, vol. 31, no. 4, pp. 67-96, Spring 2007.

8 Boeing AGM-69 'SRAM'," available from http://www.strategic-air-command.com/missiles/AircraftLaunched_Missiles/agm-69_SRAM_missile.htm.

9 Government Accountability Office (GAO), Justification for the Short Range Attack Missile II, December 1987, GAO/NSIAD-88-81B.

10 AGM-131, Directory of U.S. Military Rockets and Missiles, http://www.designationsystems.net/dusrm/m-131.html.

11 GAO, Unclassified Summary of GAO's SRAM II/T Classified Report, enclosure to a GAO memo to Defense Secretary Aspin, 24 February 1992, GAO/NSIAD-92-145R.

12 Vice Adm Timothy Keating Briefing via Satellite-Teleconference from Bahrain, 12 April 2003, News Transcript released by the Office of the Assistant Secretary of Defense for Public Affairs, available from http://www.defense.gov/transcripts/transcript.aspx?transcriptid=2370.

13 Photograph : Mehdi Fedouach/AFP/Getty Images. March 29, 2003, Buyukmerdes, Turkey; credited by Jeffrey Lewis, Why the Navy Should Retire TLAM/N, 13 December 2009, The Arms Control Wonk, available from http://lewis.armscontrolwonk.com/archive/2560/why-the-navy-should-retire-tlam-n.

14 America's Strategic Posture; The Final Report of the Congressional Commission on the Strategic Posture of the United States, 2009, U.S. Institute of Peace Press, Washington, DC, available from the Institute of Peace website, http://www.usip.org/files/America's_Strategic_Posture_Auth_Ed.pdf.

15 An unofficial translation of the original Japanese-language letter is available from the Citizens' Nuclear Information Center, http://icnndngojapan.files.wordpress.com/2010/01/20091224_okada_letter_en.pdf. 
16 Joint Communique, The $42^{\text {nd }}$ Meeting of the U.S.-ROK Security Consultative Meeting, October 8, 2010, Washington, DC, available from the Department of Defense website, http://www.defense.gov/news/d20101008usrok.pdf.

17 Joint Statement issued at the conclusion of the June 21, 2011 U.S.-Japan Security Consultative Committee meeting, attended by Secretary of State Hillary Rodham Clinton, Secretary of Defense Robert M. Gates, Minister for Foreign Affairs Matsumoto, and Minister of Defense Kitazawa, Toward a Deeper and Broader U.S.-Japan Alliance: Building on 50 Years of Partnership, available from the State Department website, http://www.state.gov/r/pa/prs/ps/2011/06/166597.htm.

${ }^{18}$ Martin Marietta LGM-118A 'Peacekeeper' ICBM Fact Sheet, available at the Hill AFB website, http://www.hill.af.mil/library/factsheets/factsheet.asp?id=5762, posted 19-Oct-2010.

19 Steven A. Pomeroy, Echoes That Never Were: American Mobile Intercontinental Ballistic Missiles, 19561983, doctoral dissertation, Auburn University, 14 April 2006, report no. CI04-1762.

20 See, for example, Art Hobson, The ICBM Basing Question, Science and Global Security, vol. 2, pp. 152198, 1991.

21 Steven A. Pomeroy, Echoes That Never Were: American Mobile Intercontinental Ballistic Missiles, 19561983, doctoral dissertation, Auburn University, 14 April 2006, report no. CI04-1762.

22 All It Touched off Was a Debate, opinion by Fred Kaplan, published 18-Sep-2005, available at the New York Times website at http://www.nytimes.com/2005/09/18/weekinreview/18kaplan.html?pagewanted=all\&_r=0.

23 Unarmed Midgetman Missile a Failure in First Test, Andrew Rosenthal, New York Times, published 12May-1989.

24 Modernizing U.S. Strategic Offensive Forces: Costs, Effects, and Alternatives, Congressional Budget Office, November 1987, pg. Summary xix.

25 Historical Overview of the Space and Missile Systems Center, 1954-2003, United States Air Force, available through the Los Angeles AFB website at http://www.losangeles.af.mil/shared/media/document/AFD-120802-071.pdf.

26 U.S. Air Force Fact Sheet: Small ICBM Hard Mobile Launcher, available via the Hill AFB website at http://www.hill.af.mil/library/factsheets/factsheet_print.asp?fsID=5717\&page=1.

27 Pat McKenna, A Taxonomy of Definitions and Types of Instability, provided for the U.S. Strategic Command, 20 November 2000, unpublished. 